\title{
Monetary and Fiscal Policies Some Problems of Coordination
}

\author{
NGUYẼ̃N TH!̣ KIM THANH \\ Email: nguyenthikimthanh61@yahoo.com
}

\begin{abstract}
The Vietnam's government, in its socioeconomic development plan for 2013, confirms the following overall targets: macroeconomic stability, a lower inflation rate, a higher growth rate, promotion of three strategic breakthroughs associated with restructuring of the economy, and a new economic growth model to ensure social security and welfare, higher efficiency in diplomatic activities and international integration, national defense, and sociopolitical stability at the service of sustainable economic development in upcoming years. Accordingly, GDP is expected to rise by 5.5\%; export turnover goes up by some 10\%; the trade gap is pegged at the $8 \%$ level, budget overspend is kept at 4.8\% of GDP at most, CPI increases by $8 \%$, the gross investment equals 30\% of GDP; the ratio of poor households reduces by $2 \%$ and the ratio of poor localities decreases by 4\%. The government also indicates a need to coordinate fiscal and monetary policies to curb inflation, enhance the macroeconomic stability, settle setbacks, enable enterprises to access sources of capital, cool down the interest rate in conformity with reduction in inflation rate, and encourage commercial banks to extend low-interest loans to the fields of agriculture and export production.

The present paper is based on the theories of relationship between fiscal and monetary policies to indicate aspects that need coordination when implementing these two policies in Vietnam at present to carry out effectively Governmental Resolution concerning the 2013 socioeconomic development.
\end{abstract}

Keywords: fiscal policy, monetary policy, impacts of plan 


\section{MONETARY POLICY, FISCAL POLICY AND THEIR RECIPROCAL IMPACTS}

The monetary policy is the collection of measures and instruments employed by the central bank to regulate the supply of money, interest rate and credit supply. Specifically, it is through manipulation of cash flows and cash amount to curb inflation and gain macroeconomic goals. A loose monetary policy can push the money supply up, reduce interest rate; and thereby increasing investment, aggregate demand, and perhaps the inflation rate if the money supply exceeds the potential output of production. By contrast, a tight monetary policy hinders the aggregate demand, and thus inflation can be manipulated.

With regard to the fiscal policy whose targets are to influence orientations for the economic development by means of policies on public expenditure and taxes, it is reflected by viewpoints, mechanism, and mode of mobilization of financial sources which constitute the national budget and centralized financial funds at the service of budget expenditures in each period. Budget expenditure and income supported by taxes have direct impacts on the macroeconomic variables such as growth rate and inflation. A loose fiscal policy can put a pressure on market prices via the two main channels namely aggregate demand and financing. In terms of aggregate demand, a loose fiscal policy can boost the domestic demand for goods. If the domestic supply cannot meet the market demand, rises in market prices are inevitable; and as a domino effect, it can promote the demand for imports, devalue domestic currency, and appreciate the value of imports.

Theories of relationship between the monetary policy and the fiscal policy presented by IS-LM and IS-LM-BP models indicate a reciprocal relationship between them. Any changes in one policy can sharply impinge on the other. For example, let us consider how changes in the fiscal policy, either loosening by enhancing government spending or tightening by cutting back government spending, do impact on the economy. According to the IS-LM model, if the central bank retains the money supply, the rise in government spending can make income and interest rate increase; yet vice versa, if the central bank would not like to raise the interest rate, the rise in the money supply is compulsory, and thus the interest rate is frozen and the income (output) will rise higher than the income gained when the money supply is kept intact. 
A tightening fiscal policy reduces government spending and makes the output go down; and thus the money supply must be boosted if the central bank wants to maintain a high output. Apparently, the government cutting back on its spending and loosening the monetary policy will push the money supply up and decrease the interest rate, which casts effects on the allocation of economic resources while the income (output) does not change. The low government spending causes the consumption to slump while the low interest rate encourages investment. In sum, it is possible to recognize the important role of the monetary policy in neutralizing impacts of fiscal policy; and thus when analyzing changes in a policy, it is necessary to presuppose their impacts on the other.

In an open economy, the IS-LM-BP model (or Mundell-Fleming model) shows that the monetary policy plays the keynote role in assuring an external balance while the fiscal policy assuring an internal balance. Although the analyses presented by this model have changed, primary analyses by Mundell and Fleming are still valuable in studying how monetary and fiscal policies work in the market with free capital movement. They employ their model to draw results of imperfect capital movement which are then utilized to formulate a significant theory named "the impossible trinity." [1]

Different countries adopt different policies in order to influence both domestic sectors (internal economic balance) and foreign-related sector (external economic balance). In order to maintain both the internal and external economic balance, a country must employ both fiscal and monetary policies. The Mundell-Fleming Model shows that a loose monetary policy can drive the interest rate down and increase deficit in the balance of payments. On the other hand, a tight monetary policy will raise the interest rate and the balance of payments surplus. Identically, when considering impacts of expanding the fiscal policy, it is visible that loosening the fiscal policy can generate the balance of payments surplus. The model also proves that the monetary policy cannot increase the output under a fixed exchange rate. With a fixed exchange rate and a perfect capital movement, international capital flows can strongly affect the money supply of the host country. It is impossible to execute a sovereign monetary policy with a view to gaining targets of output enhancement or inflation manipulation under the fixed exchange rate regime. This explains why the floating exchange rate is more effective than the fixed one. The latter does not provide the government with 
more options to execute a monetary policy while the former allows governments achieve both targets.

When formulating monetary policy or the exchange rate policy, central banks often weigh up conflicts and trade-off caused by the impossible trinity. The impossible trinity is produced from a research by Mundell and considered as a guiding star for central banks to plan their policy. At the present, it is still a controversial issue. Yet, the stability of the exchange rate or the sovereignty of the monetary policy depends on the economic health and the development level of each country. When capital flow to a country is to bridge deficits in current accounts, the formulation of an appropriate monetary policy becomes problematic because a policy to settle an issue can exacerbate another. There are even contradictions between targets of internal and external balance.

More specifically, changes in a policy can impact on the end or intermediate targets of the other policy in the following aspects:

\section{a. The Fiscal Policy Influences the Monetary Policy:}

When considering the balance sheet of the banking sector, the government incomes and spending are reflected by transactions on the bank account opened at the central bank or a commercial bank. The government deposit in the central bank is a crucial component of the monetary base, and thus is also one of factors affecting the M2 of the economy. In the periods when the government spending and income are busy, the bidirectional transfer using its account in the central bank can change the monetary base of the central bank. The practicality in Vietnam and many other developing countries has proven that the exorbitant level of deposits in a certain period of time can reduce the disposable capital of commercial banks, and thus boost the inter-bank lending rate; and by contrast, it sometimes enhances disposable capital in banks and reduces the inter-bank lending rate. This puts certain pressure on the manipulation of money supply when the central bank implements the monetary policy. Particularly, in the banking system of Vietnam where a large amount of treasury deposits are placed in commercial banks, the central bank's manipulation of money supply and interest rate is more difficult.

Sources of income to cover budget deficit also have great impacts on the monetary policy. If the budget deficit is bridged by printing money, it will increase the money supply and inflation. If budget deficit is financed by commercial loans, it tends to 
crowd out loans for non-public sectors and reduce their demand for investments. Consequently, the economic growth will deteriorate. If foreign loans represent an exorbitant percentage, the balance of payments will be adversely affected.

In the long run, the fiscal policy can impinge on the stability of the monetary policy. Manifestly, if a fiscal policy is less sustainable, it influences goals of the monetary policy. The continuous and enormous budget deficit plus giant debts of the government may reduce trust in the economy and cause the stability of the finance market. Mistrust of the government's financial sustainability can be a latent factor menacing markets for bonds, exchange rate and even the monetary regime.

In addition, the fiscal policy also affects foreign capital movement; and the central bank may face difficulty manipulating inflows and outflows of foreign capital. If a fiscal spending and income policy is inappropriately formulated, it can adversely affect the allocation of resources, which can boost risks to international capital flows. For example, a preferential tax policy for a particular industry or the government's preferential investment projects can result in a decision-making process based on tax incentives instead of the business performance or productivity. Moreover, huge public investments in a certain field or industry can cause an imbalance between the supply and the demand in this field or industry. Accordingly, the problem is that too many resources are poured into fields that enjoy tax preference and the economic growth can be driven down, causing sharp fluctuations in asset prices as well as negative impacts on financial assets of related banks.

\section{b. The Monetary Policy Affects the Fiscal Policy:}

The monetary policy, whether it is tightened or loosened, impinges on the effectiveness of the fiscal policy. A tight monetary policy affects the government's incomes due to the fact that it raises the interest rate and hinders investments, and thereby affecting the government's tax collectibles, government bond price, and the budget balance. A loose monetary policy will boost the exchange rate (i.e. devaluing the domestic currency against a foreign currency), and thereby raising the government's debts in the foreign currency.

The above-mentioned analyses indicate that the fiscal and monetary policies are interdependent and a change in a policy can influence the effectiveness of the other. Moreover, these two policies, indeed, are governed by two different agencies, so it is necessary to combine them so as to avoid unexpected risks. Vietnam's situation shows 
that in order to assure the effectiveness of these two policies, it is needed to weigh up the followings:

\section{COORDINATION OF FISCAL AND MONETARY POLICIES IN ECONOMIC MANAGEMENT}

It is necessary to be consistent in policy's goals so as to achieve macroeconomic targets such as a stable inflation rate, sustainable growth and high employment. In Vietnam, albeit basic goals of the policies are consistent, the problem is that whether the fiscal policy or the monetary policy should be opted to stimulate the aggregate demand; or that to which extent the influential level of each policy is appropriate to attain a sustainable growth, low inflation and high employment, especially in the context of economic recession and latent inflation.

The two policies should be coordinated to finance budget deficit, which is very crucial to ensure their effectiveness. A sufficient support for bridging budget deficit from the banking system (including the money supply from the central bank and loans from commercial banks) and foreign loans can improve the effectiveness of monetary and fiscal policies to a certain extent. In order to ensure a good coordination, countries often work out annually a national financial program which puts forth consistent macroeconomic solutions for carrying out a quantitative plan of macroeconomic goals. The monetary policy and the fiscal one have been linked together at all stages, from planning to implementation, to bridge the budget deficit. Moreover, instead of requesting the central bank to directly issue money, Ministry of Finance can issue government bonds to the central bank. The central bank can acquire government bonds if the money supply must be boosted; or when lack of a tool to regulate the money supply, the government, through its ministry of finance, can actively issue government bonds for the central bank to acquire. Not only does it allow the central bank an instrument for regulating the money market but the money supply can be restricted. At present, such the collaboration between the SBV and the Ministry of Finance is still constrained.

The development of the bond market is supposed to facilitate the management of public debts. Once the bond market is bullish, the liquidity of government bonds is high, and thereby attracting idle money from other sectors. Besides, the government bond market can generate a standard long-term interest rate which does not contain any latent risks, for the finance market. In this market, the central bank plays a crucial role 
in enhancing the market liquidity. The government bond is an important tool for the central bank to implement the monetary policy. By purchasing government bonds, the central bank strongly impacts on, or even changes, the bond price in the market. The tightening or loosening of the monetary policy also strongly influences the government bond price.

In implementing the two policies, it is necessary to ensure a consistency and mutual modification. The keynote goal for the central bank in implementing monetary policy is to stabilize the price and ensure a healthy financial system. In the meantime, the long-term goal of the Ministry of Finance is to minimize the government's financial loss and risks related to debt management. In order to pursue this goal, the central bank and the Ministry of Finance must collaborate with each other to execute the fiscal and monetary policies. The central bank must control the operation of the money market and the monetary base [2] so as to maintain the liquidity of the commercial banks system, stabilize the interest rate and the money market. Yet, there are also certain differences between the need to control income and expenditure by Ministry of Finance and the liquidity management of the central bank. Transactions at the National Treasury (e.g. dealing with receivables and payables, repaying debts, etc.) and those of the central bank (e.g. foreign currency exchange, changes in required reserve and open market operations, etc.) may have inconsistent impacts on the monetary base.

Therefore, the collaboration of the central bank and the Ministry of Finance and the combination of the monetary and fiscal policies are very important. There are three main problems as follows:

(i) Is it needed to issue a sufficient amount of government bonds or treasury bills to provide more tools for the monetary policy? This is a must-do task to constrain the segmentation of market and facilitate the development of a secondary market. Yet, such supplement can confuse the purpose of bridging budget deficit with that of regulating the money supply.

(ii) How to minimize the conflict between the debt management by Finance Ministry and the issue of government bonds as a tool of the monetary policy? The time and amount for issuance of government bonds is not always congruent with the demand of monetary policy. In order to tackle it, Ministry of Finance must be able to adjust the term and amount of lending to be congruent with the situation of money market. 
(iii) How to reduce effects of (daily) inflows and outflows of national budget on banks' cash balance because fluctuations in the cash balance of the National Treasury directly impact on the monetary base? This of course depends on the improvement in prediction of budget incomes and spending and punctual supply of information.

Therefore, while carrying out a fiscal policy, major incomes or expenditure of the government should be planned and notify the central bank in advance so as to proactively enable the monetary policy to work effectively and the central bank to foresee and regulate the money supply.

Management of public debts: Practical experience has indicated that the formulation of a foreign debt strategy at the service of the macroeconomic balance is really significant to Vietnam at the moment when the amount of foreign debts are going up and the effectiveness of such foreign loans is not high. The central bank holds responsible for governing the exchange rate, the foreign exchange reserve, foreign loans and debts repayment; and collecting foreign debt repayments in accordance with the applicable laws; collaborating with related agencies to prepare terms and conditions, negotiate and enter into international agreements with foreign financial institutions; and the central bank shall be the official representative of the borrower as was provided in the international convention and authorized by the government. This is to say, the state bank plays an important role in management of foreign debts of the nation and the government's public debts as well.

From the perspective of management of government's debt risks, the stability of money market, avoidance of devaluation of domestic currency, the balance of foreign currency demand and supply, and reduction of dollarization are significant to curb the increase in the government's debt expressed in national currency. Relevant authorities of all levels, especially the central bank, should assume responsibility for it.

Additionally, in order to ensure an effective coordination of fiscal and monetary policies in Vietnam, it is needed to:

- Pay attention to the macroeconomic balance in terms of consumption, accumulation, investment and trade balance. If they are maintained at an appropriate level, the monetary and fiscal policies can be combined effectively. Contrarily, in case of imbalance, problems such as high inflation, exorbitant interest rate, volatile exchange rate, huge trade gap, poor foreign exchange reserve, unstable operation of the 
banking system, etc. are inevitable; and thus the combination of the monetary and fiscal policies are less effective.

- Establish a quantitative model and analyze qualitatively the combination of fiscal and monetary policies in a certain context of the economy so as to determine the influential level of each policy on the aggregate demand and inflation rate.

- Assign a ministry to take charge of the formulation of annual and five-year financial programs, to serve as a basis for other ministries to implement macroeconomic policies which have been synchronized in terms of targets and governing solutions.

- Tighten the collaboration between the central bank and Ministry of Finance on implementation of fiscal and monetary policies. Specifically, they can propagate their viewpoints and official declarations to soothe away the public's anxiety and manipulate inflation, stabilize the market, and ensure the transparent disclosure and accountability of ministries. The central bank and Ministry of Finance should publicize empirical researches, analyses and macroeconomic predictions; exchange employees to enhance the human resource quality of the central bank and Ministry of Finance. In reality, staff of Ministry of Finance does not have expertise in monetary policy and securities market; and those of the central bank do not thoroughly understand the fiscal policy. Therefore, it is necessary to have regular training courses, staff exchange programs, etc. to enhance the quality of human resources of the two agencies.

- Stipulate specifically rights and obligations of the central bank and Ministry of Finance to reduce impacts of the government's deposits on the central bank's governance of total liquidity, and enable the central bank to utilize the government's deposits as a tool to regulate the monetary policy. For example, decision on interest rate for government bonds has not matched the state bank's interest rate policy. In some foreign countries, the interest rate of government bonds is used to orient the market rate, thus this interest rate must fluctuate in the same direction with the central bank's interest rate.

- According to World Bank and IMF (2001), in order to establish a tight collaboration between the central bank and Ministry of Finance, some countries have set up a board comprised of representatives of Ministry of Finance, National Treasury, and Central Bank. Some countries both ensure the sovereign operation of the central bank and stipulate the collaboration between the central bank and the ministry of 
finance with a view to maintaining the consistency of monetary policy goals of the central bank.

Apparently, monetary and fiscal policies are two important tools of macroeconomic management in every country. Each policy has its own goals; yet they follow macroeconomic aims such as sustainable economic development, inflation manipulation and high employment. Albeit objects of each policy are different, they are closely related and have reciprocal effects on each other. Therefore, there should be a close cooperation to implement the two policies so as to ensure the consistency of goals and the reciprocal modification. The information exchange between the two agencies is also advised so as to ensure the two policies' effectiveness and gain intended goals as well as the sustainability.

\section{Note:}

[1] The impossible trinity is also known as the Trilemma in international economics which states that it is impossible to have all of the following three macroeconomic targets (a fixed exchange rate, free capital movement, an independent monetary policy) at the same time, yet two simultaneously. The term "impossible trinity" is utilized to refer to the fragility of an economy which intentionally pursues all three goals simultaneously.

It is merely possible for a country to pursue two out of three goals. In order to gain goals of perfect capital movement and fixed exchange rate, it must renounce a sovereign monetary policy. In order to gain a perfect capital movement and a sovereign fixed exchange rate, it must float the exchange rate. In order to gain a fixed exchange rate and a sovereign monetary policy, it must restrict the capital movement. Nowadays, many countries formulate their policies with a reference to the impossible trinity. For example, in order to gain a sovereign monetary policy and a perfect capital movement, the US must sacrifice its fixed exchange rate and float its dollars.

[2] The monetary base is such a problem toward the money market and national budget due to the fact that:

The monetary base $\mathrm{H}$ is comprised of reserves (i.e. required reserve -RR- and excess reserve ER- deposited in the central bank) and currency in circulation (CIC). The amount of monetary base is identified by transactions that affect the net foreign asset (NFA), the net domestic credit to the government (NDCG), the net credit to banks (NCOB), the net credit to other financial institutions (NCOFI) and other items net (OIN).

$$
\begin{aligned}
& \Delta \mathrm{H}=\Delta \mathrm{NFA}+\Delta \mathrm{NDA} \\
& \Delta(\mathrm{RR}+\mathrm{ER}+\mathrm{CIC})=\Delta(\mathrm{NFA}+\mathrm{NDCG}+\mathrm{NCOB}+\mathrm{NCOFI}+\mathrm{OIN})
\end{aligned}
$$




\section{References}

Doughty, A. (1991), “The Relationship between Fiscal Policy and Monetary Policy”, Reserve Bank Bulletin, Vol.54

Dương Thu Hương (2012), "Một vài suy nghĩ về phối hợp CSTK và CSTT trong điều hành kinh tế vĩ mô hiện nay" a speech delivered at the workshop on coordination of fiscal and monetary policies in October 2012.

Hilbers, P. (2005), Interaction of Monetary and Fiscal Policies, IMF European Department, International Monetary Fund

Togo, E. (2007), Coordinating Public Debt Management with Fiscal and Monetary Policies: An Analytical Framework, Banking and Debt Management Department, World Bank

Vietnam's National Assembly (2009), Law on Public Debts Management

Vietnam's National Assembly (2010), Law on State Bank 